\title{
Implication on Milk Protein and Milk Lactose by Supplementing Copper and Zinc to Kankrej Cattle in Pre and Postpartum Stage
}

\author{
Narender Kumar Poonia ${ }^{1}$, Arun Kumar Jhirwal ${ }^{1}$, Subhash Chandra Goswami ${ }^{1}$, \\ Mohan Lal Choudhary ${ }^{1}$ and Garima Choudhary ${ }^{2}$
}

${ }^{1}$ Department of Livestock Production Management, ${ }^{2}$ Department of Animal Genetics and Breeding, College of Veterinary and Animal Science, RAJUVAS, Bikaner, Rajasthan, India

*Corresponding author

\begin{tabular}{|c|c|}
\hline & A B S T R A C T \\
\hline & \multirow{4}{*}{$\begin{array}{l}\text { Dietary nutrients not only affect productive and reproductive performance but also milk } \\
\text { composition traits like milk protein and milk lactose. This study was conducted to observe } \\
\text { effect of copper and zinc feeding on milk protein and milk lactose when these are fed in } \\
\text { pre and post partum stage to kankrej cows. Twenty Kankrej pregnant cows (five in each } \\
\text { group) at } 30 \text { days before the expected date of calving were used to present study and } \\
\text { grouped into four groups (five in each group) as control, copper supplemented, zinc } \\
\text { supplemented and supplemented with both elements. Milk lactose and protein percentage } \\
\text { were observed highest when both nutrient were fed together. The protein content was } \\
\text { significantly (P } \leq 0.01 \text { ) higher on the day } 7^{\text {th }} \text { of lactation and there was a decrease up to the } \\
\text { day } 45^{\text {th }} \text {. The milk lactose content }(\%) \text { was significantly (P } \leq 0.05 \text { ) lower at day } 45^{\text {th }} \text { of } \\
\text { lactation. There was no significant effect of interaction due to the group x days. }\end{array}$} \\
\hline $\begin{array}{l}\text { Kankrej, Copper, } \\
\text { Zinc, Milk protein, } \\
\text { Milk lactose }\end{array}$ & \\
\hline Article Info & \\
\hline $\begin{array}{l}\text { Accepted: } \\
\text { 15 November } 2018 \\
\text { Available Online: } \\
\text { 10 December } 2018\end{array}$ & \\
\hline
\end{tabular}

\section{Introduction}

Minerals are important for all physiological processes in animals including reproduction, production and immune system. There was scientific evidence that the nutrient status of lactating dairy cows can have a direct can have a bearing on production performance, reproduction performance and health status. Trace minerals and vitamins which influence udder health, milk production and milk quality include Selenium (Se), vitamin E, Copper, Zinc and vitamin A (Rourke, 2009). Animal breeders want to improve milk quality as well as milk production. Copper and Zinc or both supplements in the ration of the animals not only improves health and productive performance of an animal but also quality parameters of milk.

Copper $(\mathrm{Cu})$ and $\mathrm{Zinc}(\mathrm{Zn})$ are important trace minerals in dairy cattle feeding, as both elements are widely distributed in the body. Cope et al., (2009) reported that the micronutrient $\mathrm{Zn}$ is an essential component of the dairy cow's diet for maintaining health and performance. 
Kincaid and Cronrath (1992) found that Zn primarily binds to casein and to a small extent, to citrate in cow milk. Almost $90 \%$ of $\mathrm{Zn}$ binds to casein in mature milk in contrast to just $60 \%$ in the colostrums.

Scaletti and Harmon (2012) shown that organic supplementation of micro minerals has been associated with improvements in milk yield, clinical udder score and Escherichia coli counts in milk compared with inorganic and unsupplemented dairy cows following an $E$. coli challenge. Cope et al., (2009) observed that milk composition of cows was unaffected by dietary treatment but animals that received the low level of $\mathrm{Zn}$ had higher somatic cell counts in milk. Weiss and Wyatt (2002) reported that $\mathrm{Zn}$ and $\mathrm{Cu}$ supplementation has been associated with higher antioxidant capacity of superoxide dismutase (SOD) and glutathione peroxidase (GSH-Px) respectively, resulting in reduced somatic cell counts in dairy cows.

NRC (2001) reported that trace minerals and vitamins are essential in the cow's diet to support overall health and longevity. A dairy cow's requirements for vitamins and minerals are affected by a variety of factors such as pregnancy, age and production level or for the heifer, rate of growth. Kinal et al., (2005) reported that replacing $30 \%$ of the inorganic $\mathrm{Cu}, \mathrm{Zn}$ and Manganese (Mn) for 6 weeks precalving until 305 days of lactation in dairy cows resulted in a $6.5 \%$ increase in milk yield (22.35 vs. $21.20 \mathrm{~kg} /$ day, $\mathrm{P}<0.05)$. Kincaid and Cronrath (1992) found that $\mathrm{Zn}$ primarily binds to casein and to a small extent, to citrate in cow milk. Almost $90 \%$ of $\mathrm{Zn}$ binds to casein in mature milk in contrast to just $60 \%$ in the colostrums.

Uchida et al., (2001) reported that feeding a combination of $\mathrm{Zn}$ amino acid (AA), Mn AA and $\mathrm{Cu}$ AA complexes and Co glucoheptonate to early lactation Holstein cows had no effect on milk production, milk fat and protein content and linear somatic cell counts. Cortinhas et al., (2010) reported that provision of adequate mineral and vitamin nutrition during the transition period of dairy cattle may be used as a strategy to not only enhance the cow's immunity against disease but also maintain milk quality and production.

Gilbert et al., (2011) reported that supplementation of micronutrients to peripartum Sahiwal cows not only increased the milk yield but also significantly $(\mathrm{P}<0.01)$ increased the fat and protein percentage. Maximum beneficial effect was seen in the combination group which showed a significant $(\mathrm{P}<0.01)$ increase in the fat, protein and lactose percentage as compared to the control groups.

Joksimović Todorović et al., (2016) reported that trace elements such as Copper, Zinc are indispensable nutrients for preserving major physiological functions and improving overall health state. Insufficient quantity of these microelements leads to impairment of the immune response due to metabolic and oxidative stress in dairy cows, which affect milk production also. Animal breeders want to improve not only milk production but also milk composition because milk composition has economic importance in dairy industry. The livestock sector alone contributes nearly about 25.6 per cent of current prices of total value of output in Agriculture, Fishing and Forestry sector. The overall contribution of the livestock sector in total GDP of India is nearly 4.11 per cent at current prices during 2012-13. India is the world largest producer of milk accounting for more than 18.5 per cent of world's total milk production and it also has the world's largest dairy herd. The milk production has increased from 146.3 million tonnes in 2014-15 to 155.5 in 2015-16 registering a growth of 6.27 per cent. Currently, the Indian dairy market is growing 
at an annual rate of 7 per cent. Out of the nation's total milk production about 49 per cent comes from buffaloes, about 3 per cent from goats and the remainder from dairy cows. From an environmental point of view it is desirable to reduce $\mathrm{Cu}$ and $\mathrm{Zn}$ levels in cattle feeds, minimizing faecal excretion without compromising animal health and production performance. Adding mineral supplements to animal feeds can only be justified with a proven effect on practical parameters that reflect animal health and welfare, like for example morbidity, fertility, milk somatic cell count and hoof quality in bovines. Previous reviews reported effects of the addition of $\mathrm{Cu}$ and $\mathrm{Zn}$ to dietary levels above the current physiological requirements on milk yield, milk composition of cattle. Therefore, the present study was undertaken to study the effect of supplementation of Copper and Zinc on milk composition like milk protein and milk lactose of Kankrej cattle.

\section{Materials and Methods}

Selection of experimental animals: Twenty pregnant Kankrej cows in their late gestation at 30 days before the expected date of calving were selected Cattle Yard of Livestock Research Station (L.R.S), Kodamdesar of Rajasthan University of Veterinary and Animal Sciences, Bikaner and divided into 4 groups of five each. Group-I without any supplementation was considered as a control. The experimental cows were supplemented individually with Copper (Group-II), Zinc (Group-III) and combination of Copper and Zinc (Group-IV).

Animals with previous milk yield records more than $1500-1800 \mathrm{Kg} / 305$ days of lactation were selected. Based on their milk yield and parity, the animals within the same range of yield and at the same parity were blocked and randomly allocated to one of the four different treatments.

\section{Determination of quantity of Copper and zinc which was offered to animals during feeding}

Zinc, Copper and their combination feeding was conducted 30 days before the calving of selected animals and continued after the calving till 45 days.

\section{Copper}

\section{$15.2 \mathrm{mg}$ per $\mathrm{kg}$ of DM (NRC, 2001)}

- Molecular weight of CuSO4. 5H2O = 249.68

- Atomic weight of $\mathrm{Cu}=63.546$

- Purity of the product $=99 \%$

The quantity of Copper sulfate to supplement daily was calculated as follow:

- $\quad 15.2 \mathrm{mg} \mathrm{Cu}$

- $63.546 \mathrm{mg} \mathrm{Cu}$

- $15.2 \mathrm{mg} \mathrm{Cu}$

- $5 \mathrm{H} 2 \mathrm{O}$ (pure)

- $\mathrm{CuSO} 4.5 \mathrm{H} 2 \mathrm{O}$ (pure)
$15.2 \mathrm{mg} \mathrm{Cu}$ by each $\mathrm{kg}$ of DMI $249.68 \mathrm{mg}$ CuSO $4.5 \mathrm{H} 2 \mathrm{O}$ (pure) $(249.68 \times 15.2 \mathrm{mg}) / 63.546 \mathrm{CuSO} 4$. $59.7 \mathrm{mg}$ $60.3 \mathrm{mg} \mathrm{CuSO} 4.5 \mathrm{H} 2 \mathrm{O} 99 \%$ purity by each $\mathrm{kg}$ of DMI

Based on the average requirement of DM/animal/day of $10 \mathrm{Kg}$, the daily amount of $\mathrm{CuSO} 4.5 \mathrm{H} 2 \mathrm{O}$ (99\% pure) to be supplemented was $(60.3 \mathrm{mg} \times 10)=603 \mathrm{mg}$ or $0.6 \mathrm{gm}$ 


\section{Zinc}

$31 \mathrm{mg}$ per $\mathrm{kg}$ of DM (NRC, 2001)

- Molecular weight of $\mathrm{ZnSO} 4.7 \mathrm{H} 2 \mathrm{O}=287.54$

- Atomic weight of $\mathrm{Zn}=65.38$

- Purity of the product $=99 \%$

Similarly, the quantity of Zinc sulfate to supplement daily was calculated as follow:

- $31 \mathrm{mg}$ Zinc

- $65.38 \mathrm{mg} \mathrm{Zn}$

- $31 \mathrm{mg} \mathrm{Zn}$
$31 \mathrm{mg} \mathrm{Zn}$ by each $\mathrm{kg}$ of DMI $287.54 \mathrm{mg} \mathrm{ZnSO} 4.7 \mathrm{H} 2 \mathrm{O}$ (pure) $(287.54 \times 31 \mathrm{mg}) / 65.38 \mathrm{ZnSO} 4.7 \mathrm{H} 2 \mathrm{O}$ (pure) $136.3 \mathrm{mg} \mathrm{ZnSO} 4.7 \mathrm{H} 2 \mathrm{O}$ (pure) $137.6 \mathrm{mg} \mathrm{ZnSO} 4.7 \mathrm{H} 2 \mathrm{O} 99 \%$ pure by each $\mathrm{kg}$ of DMI

Based on the average requirement of DM/animal/day of $10 \mathrm{Kg}$, the daily amount of $\mathrm{ZnSO} 4.7 \mathrm{H} 2 \mathrm{O}(99 \%$ pure) to be supplemented was $(137.6 \mathrm{mg} \times 10)=1376 \mathrm{mg}$ or $1.3 \mathrm{gm}$

\section{Collection of samples}

For analysis of milk parameters, samples were collected at the day $7^{\text {th }}, 15^{\text {th }}, 30^{\text {th }}, 45^{\text {th }}$ day postpartum. About $100 \mathrm{ml}$ of milk samples from individual animals of each milking were collected in a properly cleaned milk sample bottle and these samples were kept for two hours after collection and then stirred well for minimum 5 minutes by vertical and circular slow movements. The samples were brought to the laboratory immediately after collection and placed in refrigerator till use.

\section{Preparation of sample for analysis}

The milk samples were pre warmed at $39-40^{0}$ $\mathrm{C}$ before analysis. Then samples were poured slowly from one vessel to another vessel by slightly tilting the vessel and using the side walls of the vessel to avoid formation of foams for the equal distribution of fat within the sample.

\section{Analysis of the sample}

After preparation of milk samples milk composition parameters like milk protein and milk lactose were estimated by automatic milk analyzer at Urmul dairy Bikaner.

\section{Accuracy of milk analyzer}

Accuracy of milk analyzer was checked by comparing the analyzed data of some measuring parameters with the corresponding reference method of analysis (Kjeldhal for milk protein etc.). If there was discrepancy then correction and calibration had done.

\section{Statistical analysis}

The data collected during the present investigation were subjected to statistical analysis by adopting appropriate methods of analysis of variance as described by Snedecor and Cochran (1994). Wherever, the variance ratio (F-values), were found significant at $5 \%$ and $1 \%$ level of significance.

The significance of mean difference was tested by Duncan's New Multiple Range Test (DMRT) as modified by Kramer (1957).

Data were analyzed by general linear model analyses which include the effect of treatment (supplementation of Copper and Zinc), effect of days as well as interaction effect between treatment and days for various parameters studied. 


\section{Results and Discussion}

\section{Milk protein percentage}

The least square means of milk protein content in control group and cows supplemented with Copper, Zinc and combination of both during the early lactation have been presented in Table 1(a).

The overall mean values for protein percent in milk during the experimental period were 3.52 in control cows and 3.88, 4.04 and 4.37 respectively for the cows supplemented with Copper, Zinc and their combination. The results revealed that the protein content $(\%)$ was statistically higher in combination followed by Zinc, Copper and control group. The group wise multiple comparisons between days showed that the protein content was significantly $(\mathrm{P} \leq 0.05)$ higher on the day $7^{\text {th }}$ of lactation and there was a decrease up to the day 45. There was no significant difference in milk protein percent between supplemented Copper and Zinc group as presented in Table 1(a).

Analysis of variance of milk protein percentage in control and supplemented cows with Copper, Zinc and combination of both groups up to 45 days fortnightly interval of lactation is presented in Table 1(b).

Protein percentage of milk differed significantly $(\mathrm{P} \leq 0.01)$ between groups as well as between different days of lactation period. There was no significant effect due to the interaction of group $\mathrm{x}$ days on cows of various group as shown in Table 1(b).

Table.1 Supplementation of micronutrients around peripartum and postpartum period to Kankrej cows

\begin{tabular}{|c|c|c|c|}
\hline Groups & $\begin{array}{c}\text { No. of } \\
\text { Animals }\end{array}$ & Treatment & Dose/Animal/day \\
\hline $\begin{array}{c}\text { Control } \\
\begin{array}{c}\text { Supplemented } \\
\text { Copper }\end{array}\end{array} 5^{\text {Supplemented }}$ & 5 & Nil & Control \\
\hline $\begin{array}{c}\text { Zinc } \\
\text { Supplemented } \\
\text { Combination }\end{array}$ & 5 & Copper & $15.2 \mathrm{mg} / \mathrm{kg}$ DMI \\
\hline
\end{tabular}

Table.1a Mean $( \pm$ SE) of fortnightly milk protein percentage of control Kankrej cows and cows supplemented with Copper, Zinc and their combination

\begin{tabular}{|l|c|c|c|c|c|}
\hline \multirow{2}{*}{\multicolumn{1}{|c|}{ Groups }} & \multicolumn{4}{|c|}{ Days of lactation } & Overall \\
& ${\mathbf{7}^{\text {th }}}^{\text {th }}$ & $\mathbf{1 5}^{\text {th }}$ & $\mathbf{3 0}^{\text {th }}$ & $\mathbf{4 5}^{\text {th }}$ & mean \\
\hline Control & $3.78 \pm 0.19$ & $3.62 \pm 0.07$ & $3.42 \pm 0.06$ & $3.26 \pm 0.08$ & $3.52^{\mathrm{a}} \pm 0.07$ \\
\hline Supplemented Copper & $4.13 \pm 0.26$ & $3.94 \pm 0.16$ & $3.74 \pm 0.21$ & $3.68 \pm 0.14$ & $3.88^{\mathrm{b}} \pm 0.10$ \\
\hline Supplemented Zinc & $4.32 \pm 0.21$ & $4.11 \pm 0.25$ & $3.87 \pm 0.19$ & $3.85 \pm 0.24$ & $4.04^{\mathrm{b}} \pm 0.11$ \\
\hline $\begin{array}{l}\text { Supplemented } \\
\text { combination }\end{array}$ & $4.52 \pm 0.18$ & $4.42 \pm 0.16$ & $4.34 \pm 0.17$ & $4.21 \pm 0.18$ & $4.37^{\mathrm{c}} \pm 0.08$ \\
\hline Overall mean \pm SE & $4.19^{\mathrm{b}} \pm 0.11$ & $4.02^{\mathrm{ab}} \pm 0.10$ & $3.84^{\mathrm{a}} \pm 0.10$ & $3.75^{\mathrm{a}} \pm 0.11$ & - \\
\hline
\end{tabular}

Note - The values bearing different superscripts $(a, b, c \ldots)$ differ significantly $(\mathrm{P} \leq 0.05)$. 
Table.1b Analysis of variance of milk protein percentage of control Kankrej cows and cows supplemented with Copper, Zinc and their combination

\begin{tabular}{|c|c|c|c|c|c|c|}
\hline Source of variation & DF & SS & $\begin{array}{c}\text { Mean Sum of } \\
\text { squares }\end{array}$ & F Ratio & $\mathrm{F}(5 \%) \mathrm{S} / \mathrm{N}$ & $\mathrm{F}(\mathbf{1 \%}) \mathrm{S} / \mathrm{N}$ \\
\hline Groups & 3 & 7.568 & 2.522 & 14.46 & $2.76^{*}$ & $4.13^{* *}$ \\
\hline Days & 3 & 2.286 & 0.762 & 4.36 & $2.76^{*}$ & $4.13^{* *}$ \\
\hline Groups x Day & 9 & 0.134 & 0.014 & 0.08 & $2.1^{\mathrm{NS}}$ & $2.82^{\mathrm{NS}}$ \\
\hline Residual & 64 & 11.16 & 0.174 & - & - & - \\
\hline
\end{tabular}

Asterisks indicate level of significance $(* * \mathrm{P} \leq 0.01, * \mathrm{P} \leq 0.05)$

Table.2a Mean $( \pm$ SE) of fortnightly milk lactose percentage of control Kankrej cows and cows supplemented with Copper, Zinc and their combination

\begin{tabular}{|l|c|c|c|c|c|}
\hline \multirow{2}{*}{ Groups } & \multicolumn{4}{c|}{ Days of lactation } & Overall \\
\cline { 2 - 6 } & ${\mathbf{7}^{\text {th }}}^{*}$ Control & $\mathbf{1 5}^{\text {th }}$ & $\mathbf{3 0}^{\text {th }}$ & $\mathbf{4 5}^{\text {th }}$ & mean \\
\hline Supplemented Copper & $4.53 \pm 0.07$ & $4.47 \pm 0.11$ & $4.30 \pm 0.07$ & $4.16 \pm 0.02$ & $4.36^{\mathrm{a}} \pm 0.05$ \\
\hline Supplemented Zinc & $4.98 \pm 0.14$ & $4.78 \pm 0.16$ & $4.56 \pm 0.19$ & $4.42 \pm 0.14$ & $4.68^{\mathrm{b}} \pm 0.08$ \\
\hline Supplemented combination & $5.14 \pm 0.08$ & $4.95 \pm 0.14$ & $4.70 \pm 0.14$ & $4.55 \pm 0.13$ & $4.84^{\mathrm{b}} \pm 0.08$ \\
\hline Overall mean \pm SE & $5.52 \pm 0.03$ & $5.42 \pm 0.03$ & $5.31 \pm 0.08$ & $5.13 \pm 0.10$ & $5.34^{\mathrm{c}} \pm 0.04$ \\
\hline
\end{tabular}

Note - The values bearing different superscripts $(a, b, c \ldots)$ differ significantly $(\mathrm{P} \leq 0.05)$.

Table.2b Analysis of variance of milk lactose percentage of control Kankrej cows and cows supplemented with Copper, Zinc and their combination

\begin{tabular}{|c|c|c|c|c|c|c|}
\hline Source of variation & DF & SS & $\begin{array}{c}\text { Mean Sum } \\
\text { of squares }\end{array}$ & F Ratio & $\mathrm{F}(5 \%) \mathrm{S} / \mathrm{N}$ & $\mathrm{F}(1 \%) \mathrm{S} / \mathrm{N}$ \\
\hline Groups & 3 & 10.01 & 3.3386 & 47.604 & $2.76^{*}$ & $4.13^{* *}$ \\
\hline Days & 3 & 2.654 & 0.8848 & 12.616 & $2.76^{*}$ & $4.13^{* *}$ \\
\hline Groups x Days & 9 & 0.145 & 0.0161 & 0.2300 & $2.1^{\mathrm{NS}}$ & $2.82^{\mathrm{NS}}$ \\
\hline Residual & 64 & 4.488 & 0.0701 & - & - & - \\
\hline
\end{tabular}

Asterisks indicate level of significance $(* * \mathrm{P} \leq 0.01, * \mathrm{P} \leq 0.05)$

In conclusion, these data suggest that $\mathrm{Zn}$ and $\mathrm{Cu}$ supplementation to dietary levels above recommendations for cows may have a positive effect on milk performance and milk protein. Similar results were reported by Uchida et al., (2001) and Kincaid and Cronrath (1992).

\section{Milk lactose percentage}

The milk lactose percentage least square mean results for the control and cows supplemented with Copper, Zinc and combination of both during the early lactation period under the study have been presented in the Table 2(a).

The overall average values for lactose percent in milk were 4.36 in control cows and 4.68, 4.84 and 5.34 respectively for the cows supplemented with Copper, Zinc and their combination. The highest value of mean of lactose percentage was reported in supplemented combination group followed by Zinc, Copper and Control group respectively. 
The comparisons between days showed that the milk lactose content (\%) was significantly $(\mathrm{P} \leq 0.05)$ lower on day $45^{\text {th }}$ of lactation in all experimental cows. There was no significant difference in milk lactose percentages between supplemented Copper and Zinc group as presented in Table 2(a).

Analysis of variance of milk lactose percentage in control and supplemented with Copper, Zinc and combination of both cows up to 45 days fortnightly of lactation is presented in Table 2(b).

The comparisons between treatments revealed that there was significant $(\mathrm{P}<0.01)$ difference between all the supplemented cows and

Good quality milk production requires a balanced diet. Adequate mineral nutrition may be used as a strategy to optimize immune system function by the reduction of metabolic and oxidative stress; and therefore it may have a positive effect on the defense mechanisms of mammary gland against bacterial infections. In the case of the present experiment diet supplementation with $\mathrm{Cu}, \mathrm{Zn}$ and their combination was necessary. It might be due to region which known for imbalances of the soil trace elements. So there was need to provide trace nutrient as a supplementation with general feeding schedule. Zinc deficiency causes loss of appetite and disturbances in metabolism as zinc is involved in protein synthesis, carbohydrate metabolism and nucleic acid metabolism. Zn and $\mathrm{Cu}$ supplementation has been associated with higher antioxidant capacity resulting in improve health of cows. Hence, $\mathrm{Cu}$ and $\mathrm{Zn}$ supplementation showed a significant effect on milk protein and milk lactose. Maximum beneficial effect was observed in combination supplementation feeding. The group wise multiple comparisons between days showed that the protein content and lactose was significantly $(\mathrm{P} \leq 0.05)$ higher on the day $7^{\text {th }}$ of lactation and there was a decrease up to the control group. As compare among treatments there was also significant $(\mathrm{P} \leq 0.01)$ effect of supplementation of Copper, Zinc and combination group. Thus effects of treatment and days were statistically significant $(\mathrm{P} \leq 0.01)$ but the interaction due to the effect group $\mathrm{x}$ days was found non- significant as shown in Table 2(b).

It can be concluded that the effect of $\mathrm{Cu}, \mathrm{Zn}$ and their combination is favorable on milk lactose parameter of selected supplemented cows. Similar results were reported by Uchida et al., (2001), Weiss and Wyatt (2002) and Cortinhas et al., (2010).

\section{day 45 .}

From the above study it can be concluded that:

Supplementation of micronutrients improved the udder health and milk production.

Micronutrient supplementation also increased the other milk parameters such as milk lactose and milk protein.

Micronutrients supplementation provided to pregnant dam has a significant effect on milk composition.

Micronutrient supplementation also improves immunity of an animal.

Of all the micronutrients maximum beneficial effect was seen when all the micronutrients (Copper + Zinc) are fed together to the peripartum cows.

\section{Acknowledgement}

The authors are thankful to Rajasthan University of Veterinary and Animal Sciences (RAJUVAS), Bikaner for providing all type of facilities to carry out the study. 


\section{References}

Cope, C. M., Mackenzie, A. M., Wilde, D. and Sinclair, L. A. 2009. Effects of level and form of dietary zinc on dairy cow performance and health. J. Dairy Sci., 92(5): 2128-2135.

Cortinhas, C. S., Botaro, B. G., Sucupira, M. C. A., Rennó, F. P. and Santos, M. V. D. 2010. Antioxidant enzymes and somatic cell count in dairy cows fed with organic source of zinc, copper and selenium. Livest. Sci., 127(1): 84-87.

Gilbert, M. 2011. Effect of vitamin e, copper and zinc supplementation on udder health, milk production of transition sahiwal cows (Doctoral dissertation, NDRI, Karnal).

Joksimović-Todorović, M., Davidović, V. and Bojanić-Rašović, M. (2016). The effects of some microelements supplementation-selenium, zinc and copper into dairy cows feeds on their health and reproductive performances. Biotechnology in Animal Husbandry, 32(2): 101-110.

Kinal, S., Korniewicz, A., Jamroz, D., Zieminski, R. and Slupczynska, M. 2005. Dietary effects of zinc, copper and manganese chelates and sulphates on dairy cows. J. Food Agricult. Environ., 3(1): 168-172.

Kincaid, R. L. and Cronrath, J. D. 1992. Zinc concentration and distribution in mammary secretions of peripartum cows. J. Dairy Sci., 75(2): 481-484.

Kramer, C.Y. 1957. Extension of multiple range tests to group correlation

National Research Council. 2001. Nutrient Requirements of Dairy Cattle. 7th rev. edition. Natl. Acad. Sci., Washington, DC.

Scaletti, R. W. and Harmon, R. J. 2012. Effect of dietary copper source on response to coliform mastitis in dairy cows. J. Dairy Sci., 95(2): 654-662.

Uchida, K., Mandebvu, P., Ballard, C. S., Sniffen, C. J. and Carter, M. P. 2001. Effect of feeding a combination of zinc, manganese and copper amino acid complexes, and cobalt glucoheptonate on performance of early lactation high producing dairy cows. Anim. Feed Sci. Tech., 93(3): 193-203.

Weiss, W. 2002. Relationship of mineral and vitamin supplementation with mastitis and milk quality. In annual meetingnational mastitis council incorporated (Vol. 41, pp. 37-44). National Mastitis Council; 1999.

Weiss, W. P. and Wyatt, D. J. 2002. Effects of feeding diets based on silage from corn hybrids that differed in concentration and in vitro digestibility of neutral detergent fiber to dairy cows. J. Dairy Sci., 85(12): 3462-3469.

\section{How to cite this article:}

Narender Kumar Poonia, Arun Kumar Jhirwal, Subhash Chandra Goswami, Mohan Lal Choudhary and Garima Choudhary. 2018. Implication on Milk Protein and Milk Lactose by Supplementing Copper and Zinc to Kankrej Cattle in Pre and Post partum Stage. Int.J.Curr.Microbiol.App.Sci. 7(12): 2169-2176. doi: https://doi.org/10.20546/ijcmas.2018.712.246 